SCIREA Journal of Forestry

http://www.scirea.org/journal/Forestry

January 20, 2022

Volume 3, Issue 1, February 2022

https://doi.org/10.54647/forestry22023

\title{
Assessing the Insights of Community Forest Users on Scientific Forest Management in Community Forest of Nepal: A SWOT-AHP Analysis
}

\author{
Prabin Pandit ${ }^{1, *}$, Pradeep Kunwar ${ }^{2}$ \\ ${ }^{1}$ Assistant Lecturer, College of Environment and Forestry, Biratnagar, Nepal \\ ${ }^{2}$ Student, College of Environment and Forestry, Biratnagar, Nepal
}

\begin{abstract}
Implementation of scientific forest management (SciFM) plan is gradually expanding in community forest (CF) of Nepal. Meanwhile insights of CF users regarding the management of CF with implementation of SciFM plan is still unidentified. In this study we used SWOT (Strengths, Weakness, Opportunities and Threats) methods in combination with AHP (Analytical Hierarchy Process) to assess the insights. The results revealed that even with the presence of negative factors (weakness and threats) of SciFM, positive factors (strengths and opportunities) are outweighed. In addition, economically attractive, lack of appropriate technology and technical manpower, balancing growing demand of forest products and less supporting geography were the most important SWOT factors perceived by CF users. The findings suggest that SciFM in CF of Nepal is viewed as double-edge sword with challenges and benefits. Therefore, despite of the less focused of SciFM on environmental and ecological aspects of the CF, it is capable of ensuring immediate communities' benefits. Hence, uncertain benefits flow due to SciFM could disrepute the acceptability of SciFM by CF users in long run.
\end{abstract}


Keywords: Community forest; management plan; silviculture system; SWOT-AHP

\section{Introduction}

Area of the global forest managed under the community-based management is increasing, which include more than 513 million hectors of forest managed by local communities (RRI, 2014), consequently it became a solution to various environmental and social problems of developing countries through the different forest management modalities (Gilmour, 2016). Nepal is recognized as pioneer country of community forest (CF) management in Asia Pacific (Gurung et al., 2013; Pandit \& Bevilacqua, 2011), begun in late 1970's with the aim of engaging local peoples in forest management, improvement of forest condition and environmental condition and provide subsistence needs of forest products to the local peoples in the mid hills (Gurung et al., 2013; Pandit \& Bevilacqua, 2011). CF program in its early year was focused on restoration of forest in denuded hills and support basic needs of forest products to the local communities (B. Adhikari, Williams, \& Lovett, 2007; Gurung et al., 2013), later on it is viewed as reliable source of revenue in low land (terai) and mid hills of Nepal through the commercial management (Gurung et al., 2013; Jayasawal \& Bishokarma, 2016; Sapkota, Dhungana, Poudyal, Chapagain, \& Gritten, 2020).

Devolution of CF in Nepal was started after the promulgation of forest act 1993, which provide legal rights to the local communities for conservation, management, utilization and distribution of forest produce according to the operational plan (Bampton \& Cammaert, 2007; Dhakal \& Masuda, 2009; Rutt et al., 2015). In following year (1994), CF program implementation guideline was endorsed to develop the constitution and management plan of CF (GON, 2014a; Rutt et al., 2015). CF implementation guideline and CF inventory guideline 2000 (revised in 2004) combinedly provide details of management outline; harvesting level, utilization level and distribution pattern of the forest products (Sirjana Baral et al., 2018; Pandit \& Bevilacqua, 2011; Rutt et al., 2015). This devolution had brought positive outcomes in ecological, social and environmental capital formation in various level which lead to subsequent household benefits and private capital formation (Bampton \& Cammaert, 2007; Gilmour, 2016; GON, 2014a; Gurung et al., 2013; Luintel, Bluffstone, \& Scheller, 2018; Ojha, 2006; Rutt et al., 2015). CF program in Nepal is now a dominant forest management regime in Nepal, as of September 2020, 2,237,670 ha forest was managed under the CF program by 22,266 user groups (DOF, 2020). 
After 1990's communities' interest has shifted from subsistent use of forest product for basic needs fulfillment to income generation, community development and maximization of economic benefits (Rutt et al., 2015). Meanwhile despite the worldwide appreciation of CF as a fruitful model, its success in Nepal was limited only in mid hill region (Jayasawal \& Bishokarma, 2016; Pandit \& Bevilacqua, 2011; Sapkota et al., 2020). Likewise, it has been criticized for various technical and social reasons such as protection orientated management and elite capture in benefit (Forest Action, 2014; Ojha, 2006; Yadav, Yadav, Yadav, \& Thapa, 2009). Beside it's contribution to rural livelihood, CF program in Nepal failing to meet the hopes of various stakeholders, especially in palpable benefits to the local communities (Jayasawal \& Bishokarma, 2016; Sapkota et al., 2020). CF inventory guideline in Nepal was used for detail inventories of forest attributes for prescribing the harvesting level (Sirjana Baral et al., 2018; Ojha, 2006). Moreover, this inventory guideline primarily designed for the management of CF in mid hills. Therefore, without any modification it cannot bring positive outcome in productive CF of terai and mid hills region (Yadav et al., 2009). Moreover, this argument demands technical management placed on CF of Nepal (Hull, Ojha, \& Paudel, 2010). As a result, scientific forest management (SciFM) was piloted in productive Sal (Shorea robusta) forest of low land of Nepal in 2012 and formalized through the endorsement of SciFM guideline 2014 (Jayasawal \& Bishokarma, 2016).

SciFM is applied in productive forest management through the application of irregular shelterwood system with modification coppice system, seed tree system and selection system and the strong theoretical foundation of compartmentation forest with fixed rotation age (Jayasawal \& Bishokarma, 2016; Joshi, Parajuli, Kharel, Poudyal, \& Taylor, 2018; Poudyal, Maraseni, \& Cockfield, 2020). There are series of steps in the preparation of SciFM plan, which includes (i) identification of forest area; (ii) interaction with the stakeholders for the intended outcomes; (iii) survey of forest boundary, ground features and blocking of forest area; (iv) conduct inventory for the assessment of cover, growing stock, annual increment and regeneration status (v) finalization and implementation of management plan (GON, 2014b; Joshi et al., 2018). SciFM through the application of suitable silvicultural system (more commonly irregular shelterwood system) employs preparatory felling, thinning, improvement felling and final felling to generate revenue and to improve overall productivity of the forest (Jayasawal \& Bishokarma, 2016). Based on this, altogether 30 collaborative forest, 7 government managed block forest and $285 \mathrm{CF}$ was managed under SciFM shame in Nepal (Poudyal et al., 2020). 
Beside the growing attention of SciFM, various challenges had been raised on the ground by several scholars. As for example, SciFM has not been able to gain active participation of stakeholders (Bhusal, Awasthi, \& Kimengsi, 2020; Joshi et al., 2018), local communities losing their control over the forest resources (Sirjana Baral et al., 2018; Rutt et al., 2015), attempt to recentralization and blanket approach of forest management (Basnyat, Treue, \& Pokharel, 2018), silvicultural madness of forest management without considering forest type and geography (Basnyat et al., 2018) and son on. Nevertheless, in spite of the shortcomings, SciFM in Nepal increases the timber supply is deemed acceptable. scholars have argued that insights of the key stakeholder especially CF users could influences the effective implementation and sustainability of SciFM (Poudyal et al., 2020). However, the studies about user's perception on CF are limited (Bhusal et al., 2020; Joshi et al., 2018; Poudyal et al., 2020) and the understandings and knowledge of CF users regarding the forest management are not adequately documented. Therefore, this study was carried out using SWOT (Strengths, Weakness, Opportunities and Threats) methods in combination with AHP (Analytical Hierarchy Process) analysis framework to assess the CF users' insights on strengths, weaknesses, opportunities and threats of SFM in CF of Nepal.

\section{Methods}

\subsection{Study area}

This study was carried out in Gorkha and Chitwan district (Figure 1), representing two different geographic and economic settings of Nepal. Gorkha district represents the mid hills physiographic region where forest area in the past was denuded due to deforestation and gradually improved since CF program (Ojha, 2006) and recently SciFM has been introduced. Whereas, Chitwan district represents the terai physiographic region containing productive forest with high value trees (Forest Action, 2014; Ojha, 2006) and highly sensitive biological corridor. 


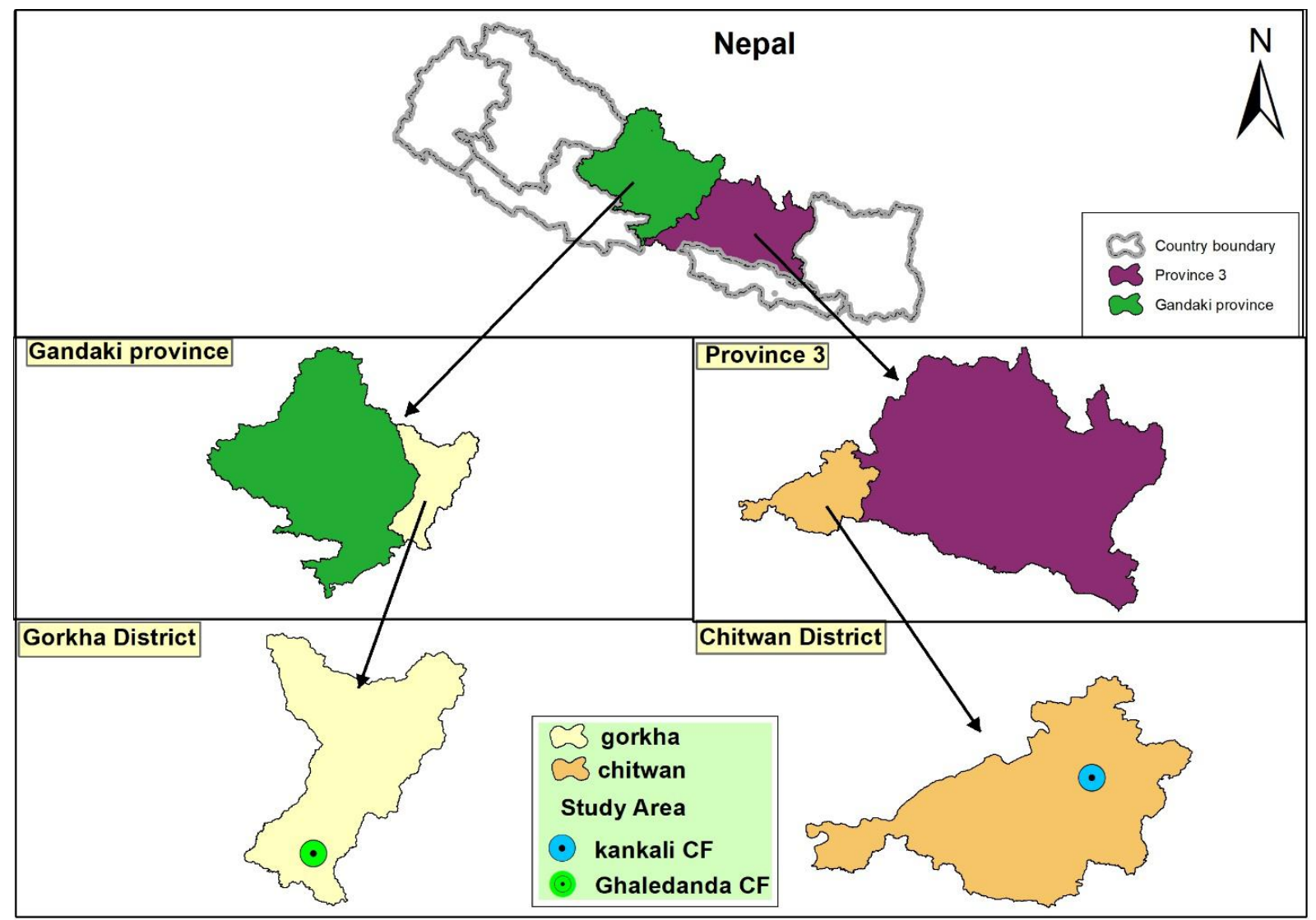

Figure. 1. Map showing study area (Gorkha, Chitwan)

One CF form each of two district was selected namely, Kankali CF from Chitwan district and Ghaledanda CF from Gorkha district in such a way that; a) CF managed with SciFM guideline $2014 \mathrm{~b}$ ) area of the CF is more than 400ha c) no. of CF user household is more than 500 and d) one CF is located in mid hill physiographic zone and another in Terai physiographic zone. Biophysical and socio-demographic information of the selected CF was presented in Table 1.

Table 1. Description of the studied CF

\begin{tabular}{|c|c|c|c|c|c|c|}
\hline Name of CF & Address & $\begin{array}{l}\text { Handover } \\
\text { fiscal year } \\
\text { of SciFM } \\
\text { plan }\end{array}$ & $\begin{array}{l}\text { Total } \\
\text { area of } \\
\text { forest } \\
\text { (ha) }\end{array}$ & $\begin{array}{c}\text { Household } \\
\text { number }\end{array}$ & Forest type & $\begin{array}{l}\text { Major forest } \\
\text { species }\end{array}$ \\
\hline Ghaledanda & $\begin{array}{c}\text { Shaid Lakhan } \\
\text { Thapa Rural } \\
\text { Municipality } \\
\text { 07, Gorkha }\end{array}$ & $\begin{array}{c}2073 / 74 \\
(2016 / 17)\end{array}$ & 475.8 & 531 & $\begin{array}{l}\text { Subtropical } \\
\text { mixed sal } \\
\text { forest }\end{array}$ & $\begin{array}{c}\text { Shorea } \\
\text { robusta, } \\
\text { Schim } \\
\text { wallichii } \\
\text { Castanopsis } \\
\text { indica }\end{array}$ \\
\hline Kankali & $\begin{array}{l}\text { Khaireni } \\
\text { Municipality } \\
\text { 04, Chitwan }\end{array}$ & $\begin{array}{c}2074 / 75 \\
(2017 / 18)\end{array}$ & 749.13 & 2098 & $\begin{array}{l}\text { Tropical } \\
\text { mixed sal } \\
\text { forest }\end{array}$ & $\begin{array}{c}\text { Shorea } \\
\text { robusta } \\
\text { Terminalia }\end{array}$ \\
\hline
\end{tabular}




\subsection{SWOT-AHP Process}

SWOT analysis is mostly used for analyzing internal (strengths, weakness) and external (opportunities, threats) settings in order to achieve a systematic approach and support for a decision situation (Wheelen \& Hunger, 2010). The internal and external factors are mentioned as the decision-making factors thus enables them to compare opportunities and threats with strengths and weaknesses (Shrestha, Alavalapati, \& Kalmbacher, 2004). In spite of the methodological heftiness of SWOT, it alone does not provide the quantitative estimate of relative importance of various SWOT factors either within a SWOT category or among the SWOT Category (Kurttila, Pesonen, Kangas, \& Kajanus, 2000; Stainback, Masozera, Mukuralinda, \& Dwivedi, 2012). The AHP method developed by (Saaty, 1977), is a mathematical method for analyzing multifaceted decisions with multi-criteria. Thus, AHP (Saaty, 1977) is a multi-criteria decision method that allows estimation of the relative importance for each SWOT factor and each SWOT category. Combined SWOT-AHP analyze systematically of internal (strengths, weakness) and external (opportunities, threats) factors persuading decision-making with a quantitative of position of each factor (Saaty \& Vargas, 2012). In this study following steps suggested in the SWOT-AHP by (Dwivedi \& Alavalapati, 2009; Kurttila et al., 2000; Stainback et al., 2012) were used for the collection and analysis of data.

First step concerned with identification of SWOT factors influencing to each SWOT category. During this process three forestry experts and four knowledgeable CF users from these two selected CF were requested to give their feedbacks separately on strengths, weakness, opportunities and threats on management of CF with implementation of SciFM plan. Forestry experts here refers to the individuals who directly or indirectly involved in different organizations working in different CF issues of Nepal. It includes; academicians, government officials and FECOFUN member. Whereas knowledgeable CF users indicate individuals who knew about the present situation of their CF and can express the community's view in the form of strengths, weakness, opportunities and challenges faced by their CF. There feedbacks and findings from the prior researches (Jayasawal \& Bishokarma, 2016; Joshi et al., 2018; Poudyal et al., 2020) was used to developed the complete list of SWOT factors in each SWOT 
category. Four most important factors in each SWOT category (see Table 2) were chosen from those lists by mutual accord of requested knowledgeable CF users and forestry expert.

In step two, four focus group discussion were conducted with the CF users to assess their insights on the SWOT factors accomplished by forestry expert and knowledgeable CF users in previous step. 10-15 CF users were participated in each focus group discussion. We requested to participate in focus group discussion from all position; general users, executive members and executive position holder. A short explanation of each SWOT factor listed in Table 2 was done in focus group discussion. Then participants were asked to make pair wise comparisons of the factors within the same SWOT category (as in Figure 2) based on their individual understandings. The pair wise comparisons were made based on the relative importance of one factor over another within each swot category using the rating scale, developed by (Saaty \& Vargas, 2012) (see appendix 1). For example, respondents were requested to mark the magnitude of factor "A" compared to magnitude of factor "B" as in Figure 2 and indicate if factor $\mathrm{A}$ and factor $\mathrm{B}$ are equally important or one factor is more important than another. If reply of the respondents was "3" on right side, it implies that factor "B" is three time more important than factor "A". Likewise, same procedure was used for the comparison of all SWOT category.

Compare the relative importance of factor A to factor B, and circle suitable number.

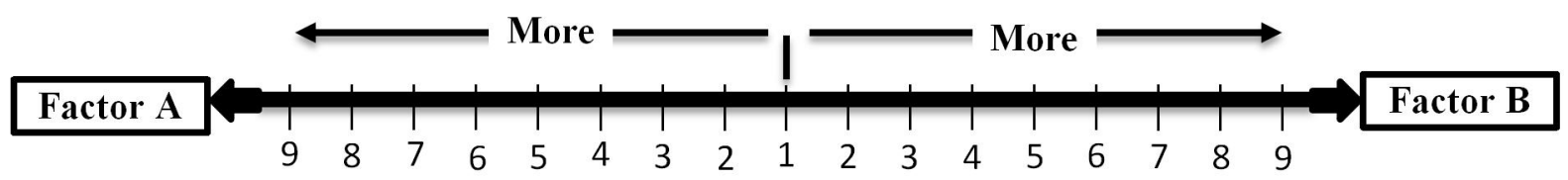

Figure. 2. Graphical illustration for a pairwise comparison among two factors. 1 signifies equal importance and moving from 2-9 left or right would indicate the factor is more important over the other factor, with 9 signifying extreme relative importance

In step three, pair wise comparison made by $10 \mathrm{CF}$ users were analyzed through AHP method. Factor priority within the group value for each SWOT factors were calculated using the eigenvalue method (see appendix 2 for detail procedure). The factor with highest priority score under each SWOT category is selected for further comparison in order to determine the priority value within the group. Finally, priority value of each SWOT group and factor priority value within the group are used to calculate the overall priority score of each factor as follow;

$($ Overall priority factor $) \mathrm{ij}=($ priority value of each SWOT group $) \mathrm{ij} *$ 
(factor priority value within the group)j

where $\mathrm{j}=4$ (strength, opportunity, weakness and threat). The sum of overall priority score is equal to 1 , with highest value indicates most important factor in decision situation of SciFM.

\section{Results and Discussion}

Overall, SWOT factors and their priority score for CF users regarding the management of CF with implementation of SciFM plan is presented in Table 2. For all tradeoff, consistency ratio was less than $10 \%$. Combined score of strengths and opportunities were interpreted as positive factor while combined score of weakness and threats as negative factor. In this study, positive factors for CF with SciFM plan implementation were found to be 0.76 (76\%) compared to the negative factors 0.23 (23\%). CF users found economically attractive, lack of appropriate technology and technical manpower, balancing growing demand of forest products and less supporting geography were the most important strength, weakness, opportunity and threat respectively. This result indicates that CF users agreed management of CF with implementation of SciFM has more benefits in compared to the challenges. Relative position of each factor within each SWOT category provides valuable evidences for decision making. For example, a priority value of 0.412 stated in column 6 of Table 2 shows CF users perceived S1 (economically attractive) alone accounts for $41 \%$ of strengths of CF managed with implementation of SciFM. Further, Figure 2 denotes SWOT factors with their respective overall priority value for CF users, determined through AHP method.

\section{Within factor priorities}

Analysis within the group factor of CF users shows that economically attractive is perceived as the most important strength of CF managed with implementation of SciFM plan. All CF users agreed that after SciFM implementation, quantity of harvestable forest products (mainly timber) were increased. findings by the prior scholar (GON 2014b; V. R. Subedi, Bhatta, Poudel, \& Bhattarai, 2018) asserts that Nepal is yearly losing 91 million USD from the forest because of inappropriate forest management practices. Likewise, CF users identified improve forest health, based on intense silvicultural management and sustainability and reduce forest fire to be the second, third and fourth most important strengths of CF managed with implementation of SciFM plan respectively. CF users believed removal of 4D (dead, dying, deformed and diseased) trees and good regeneration status in regeneration felled area would improve forest health along with construction of fires lines between two blocks prevents 
spread of forest fire in the whole forest area. Silviculture system mainly, irregular shelterwood system has demonstrated profuse natural regeneration, improved forest condition and growing stock increment in the scientifically managed forest (Awasthi et al., 2020; Poudyal et al., 2020). Moreover, (Bhusal et al., 2020; Jayasawal \& Bishokarma, 2016) found increase in production of forest produce and improvement in productivity of the forest land has been recognized as the major outcomes of SciFM. Notably, during the SciFM plan preparation and implementation process, activities like; construction of fire lines, removal of 4D trees, twigs and leaf litters from the forest floor as well as regular monitoring of forest area reduces fire incidences in the scientifically managed forest (Bhusal et al., 2020; Joshi et al., 2018) . CF users believe that lack of appropriate technology and technical manpower would be the prime weakness of this forest management. This result is expected because during the field observations and focus group discussions it was observed that $\mathrm{CF}$ users were confused about the implementation procedures and silviculture of SciFM, although they were aware about the number of annual trees to harvest. It symbolized that inadequate and insufficient technical human resources were lacking to deliver the SciFM procedure and its theoretical foundation to the CF users. (Poudyal et al., 2020) reported similar results, specific forestry experts are lacking to facilitate the SciFM program implementation. Additionally, there has been very limited use of efficient/appropriate harvesting, transportation, fire fighting tools and machines in SciFM. This result reveled the findings of (Basnyat et al., 2018; V. R. Subedi et al., 2018) that SciFM has focused on tree harvesting and employed technical resources which could be a challenging task to the forest users and unfavored forest users. Similarly, timber centric was ranked as second most important weakness of this forest management regime identified by $\mathrm{CF}$ users. Not only the timber, all the forest products found in the $\mathrm{CF}$ are important to the $\mathrm{CF}$ users. CF users also perceived that management interventions were giving preference to the high value species, sal (Shorea robusta) for producing the timber. This finding is similar to the (Basnyat et al., 2018; Ojha, 2006) who found that SciFM oriented towards commercial timber production. Likewise, CF users ranked lengthy bureaucratic harvesting process and corruption as third and fourth most important weakness of SciFM respectively. CF users often consider SciFM plan as the bureaucratic requirements. They viewed SciFM plan as a blueprint document to guides the tree to be harvest. They often feel, they were forbidden to harvest trees even following the prescription of SciFM plan. Without the permission of divisional forest office, they were not allowed to harvest trees. In this regard scholars (Sony Baral \& Vacik, 2018; Ojha, 2006) criticized SciFM as techno-bureaucratic dominance and often proclaiming for the bureaucratic control of the forest resources. CF users viewed issues 
of corruption after the implementation of SciFM plan was rampant. Agreement between timber traders and CF leaders on timber bidding process as well as leakage of timber for their own benefits, increases the corruption after the SciFM. (Banjade, 2013) found, corruption is more intense in harvesting and trading of valuable timber. This results echoes with findings of (Joshi et al., 2018) on over growing corruption in SciFM.

Table 2. Priority scores of all SWOT factors and overall priority of SWOT-AHP analysis

\begin{tabular}{|c|c|c|c|c|c|}
\hline $\begin{array}{c}\text { SWOT } \\
\text { category }\end{array}$ & Priority of the group & $\begin{array}{l}\text { SWOT } \\
\text { factors }\end{array}$ & $\mathbf{C R}$ & $\begin{array}{c}\text { Factor priority } \\
\text { within the group }\end{array}$ & $\begin{array}{l}\text { Overall } \\
\text { priority }\end{array}$ \\
\hline \multirow{5}{*}{ Strengths } & \multirow{5}{*}{0.419} & & \multirow{5}{*}{0.425} & & 0.419 \\
\hline & & S1 & & 0.412 & 0.173 \\
\hline & & S2 & & 0.354 & 0.148 \\
\hline & & S3 & & 0.135 & 0.057 \\
\hline & & S4 & & 0.099 & 0.042 \\
\hline \multirow{5}{*}{ Weakness } & \multirow{5}{*}{0.102} & & \multirow{5}{*}{3.083} & & 0.102 \\
\hline & & W1 & & 0.490 & 0.050 \\
\hline & & W2 & & 0.261 & 0.027 \\
\hline & & W3 & & 0.126 & 0.013 \\
\hline & & W4 & & 0.122 & 0.012 \\
\hline \multirow{5}{*}{ Opportunities } & \multirow{5}{*}{0.343} & & \multirow{5}{*}{1.560} & & 0.343 \\
\hline & & 01 & & 0.407 & 0.140 \\
\hline & & $\mathbf{O 2}$ & & 0.219 & 0.075 \\
\hline & & $\mathbf{O 3}$ & & 0.276 & 0.095 \\
\hline & & O4 & & 0.098 & 0.034 \\
\hline \multirow{5}{*}{ Threats } & \multirow{5}{*}{0.136} & & \multirow{5}{*}{3.455} & & 0.136 \\
\hline & & T1 & & 0.390 & 0.053 \\
\hline & & $\mathbf{T} 2$ & & 0.359 & 0.049 \\
\hline & & T3 & & 0.156 & 0.021 \\
\hline & & T4 & & 0.095 & 0.013 \\
\hline
\end{tabular}

S1: Economically attractive; S2: improve forest health; S3: based on intense silvicultural management and sustainability; S4: reduce forest fire; W1: lack of appropriate technology and technical manpower; W2: timber centric; W3: lengthy bureaucratic harvesting process; W4: corruption; O1: balancing growing demand of forest products; O2: creates green job \& enterprise; O3: community development; O4: monitoring illicit felling; T1: less supporting geography; T2: political and legal uncertainty; T3: biodiversity loss; T4: disease and other environmental hazard. 
In the opportunity category, CF users felt balancing growing demands of forest products to be the most important opportunity of SciFM plan implementation. CF users considered more trees (especially green trees, that was not usually harvested before SciFM) are available for the harvest and fulfill the growing demands of the local people. This corroborates with (Joshi et al., 2018; Poudyal et al., 2020) observed that SciFM increases the forest products supply and replace the imported forest products. Likewise, community development was found to be the second most important opportunities of SciFM. CF users group devoted more attention on development and maintenance of communities' infrastructures like; road, community buildings, schools, etc. after raising the CF funds due to SciFM. An expert assessment (Sony Baral \& Vacik, 2018; Khanal \& Adhikari, 2018) in active forest management recommended that active forest management become a vehicle for the community development. Similarly, third and fourth most important opportunities of SciFM perceived by CF users are creates green job \& enterprise and monitoring illicit felling. CF users expected to generate local employment opportunities through SciFM during harvesting, thinning, cleaning, transportation, log conversion, fuel wood collection and monitoring activities - a view support by earlier study (Bhusal et al., 2020; Joshi et al., 2018; Poudyal et al., 2020). Therefore, SciFM anticipated to creates at least 40,000 jobs annually (FRA \& DFRS, 2015; B. P. Subedi et al., 2014). Additionally, wood-based industries, timber processing and seasoning facilities and saw mills outside the CF managed with SciFM has greater scope (Bhusal et al., 2020). With implementation of SciFM, CF users have faith in; total enumeration of trees, regular monitoring by government officials and numbering of trees ease the control of illegal happenings in the CF - A view favors by an earlier study in Terai region of Nepal (Joshi et al., 2018).

Additionally, the analysis revealed that less supporting geography was perceived as the most important threats of SciFM. CF users considered geographic terrain become a challenging factor for adopting similar silvicultural practices as in Terai (flat topography) and mid hills (slope topography) of Nepal. For this reason, scholars (Basnyat et al., 2018) criticized SciFM for "one size fit all ". In addition to this, an earlier study (Basnyat et al., 2018; Joshi et al., 2018) arrive at similar findings on management of SciFM in geographical sensitive area (churia) and midhills of Nepal is questionable. The second most important weakness of SciFM was political and legal uncertainty. CF users mentioned that political situations change in the country imparted political conflicts for the position as well as personal benefits within the CF user groups in one hand and creates political biasness within the CF user group 
in other. they perused government bureaucracy is dominated by political and economic motive, results legal provisions regarding the $\mathrm{CF}$ management are uncertain to the $\mathrm{CF}$ users. In such situation, CF users clarified with example; after the constitution of Nepal 2015, CF users have to share their revenues with local government according to the local government operation act 2017. This is similar to the findings of (Bhattrai, Mandal, \& Kurmi, 2017) who found that changing political situation of the country fallouts in making new legislation by the government in the favor of $\mathrm{CF}$ users rights over the natural resources become perilous. Likewise, CF users sighted biodiversity loss followed by diseases and other environmental hazards as third and fourth most important threats of SciFM respectively. CF users observed that practice of regeneration felling, thinning and other post harvesting operation decreases species diversity, though it favored intended tree species sal (Shorea robusta). However, they were unknown about the loss of other biological diversity due to SciFM. Some of the scholar (Demarais, Verschuyl, Roloff, Miller, \& Wigley, 2017) claimed that interferences in the forest affects the intact biological diversity circuitously through the habitat alteration. In contract to this, scholar (Poudyal, Maraseni, \& Cockfield, 2019) found SciFM promoting species diversity. Regarding the species diversity in SciFM, recent study by (Awasthi et al., 2020) found SciFM enhanced profuse natural regeneration of desired tree species (Shorea robusta) buts other species diversity is decreasing simultaneously. CF users viewed diseases and other environmental hazards as a threat because SciFM employed concentrated harvest of greater number of trees even in geographically fragile area (churia) and hilly geographic region, especially landslide and soil erosion risks are more frequent in these areas. these finding resonate the findings of (Basnyat et al., 2018; Joshi et al., 2018; Poudyal et al., 2020) who reported SciFM in Nepal overlooked environmental aspects of the forest. Additionally, they lucid about the threats of SciFM because of risk of diseases. They believe that outcomes of SciFM; even aged more or less pure crops (as stated earlier) are liable to damage by environmental, biological and anthropogenic factors like; wind, frost, diseases, fire, etc. Notably, extensive establishment of even aged pure stands are more hazardous and susceptible to diseases (Boyce, 1954).

\section{Between factor priorities}

Analysis of across group factors of CF users indicated that combined overall positive value, was the sum of overall priority score of strengths and opportunities was found to be $76 \%$ and combined overall negative value, was the sum of overall priority score of weakness and threats (Dwivedi \& Alavalapati, 2009) was found to be $24 \%$ as shown in Table 2 and Figure 3. 
The strength category ( $42 \%)$ dominated the overall insights followed by opportunities $(37 \%)$, threats $(14 \%)$ and weakness $(10 \%)$. Figure 3 illustrates the distribution of overall priority score of the factors. The economically attractive (strength) with overall priority score 0.173 turned out to be the most important factor of SciFM in CF of Nepal. Improve forest health (strength) with overall priority score 0.148 followed by balancing growing demand of forest products (opportunities) with overall priority score 0.140 are shown to be second and third most important factors of SciFM respectively. Lastly, corruption (weakness) with overall priority score 0.012 was sighted as least important factor of SciFM.

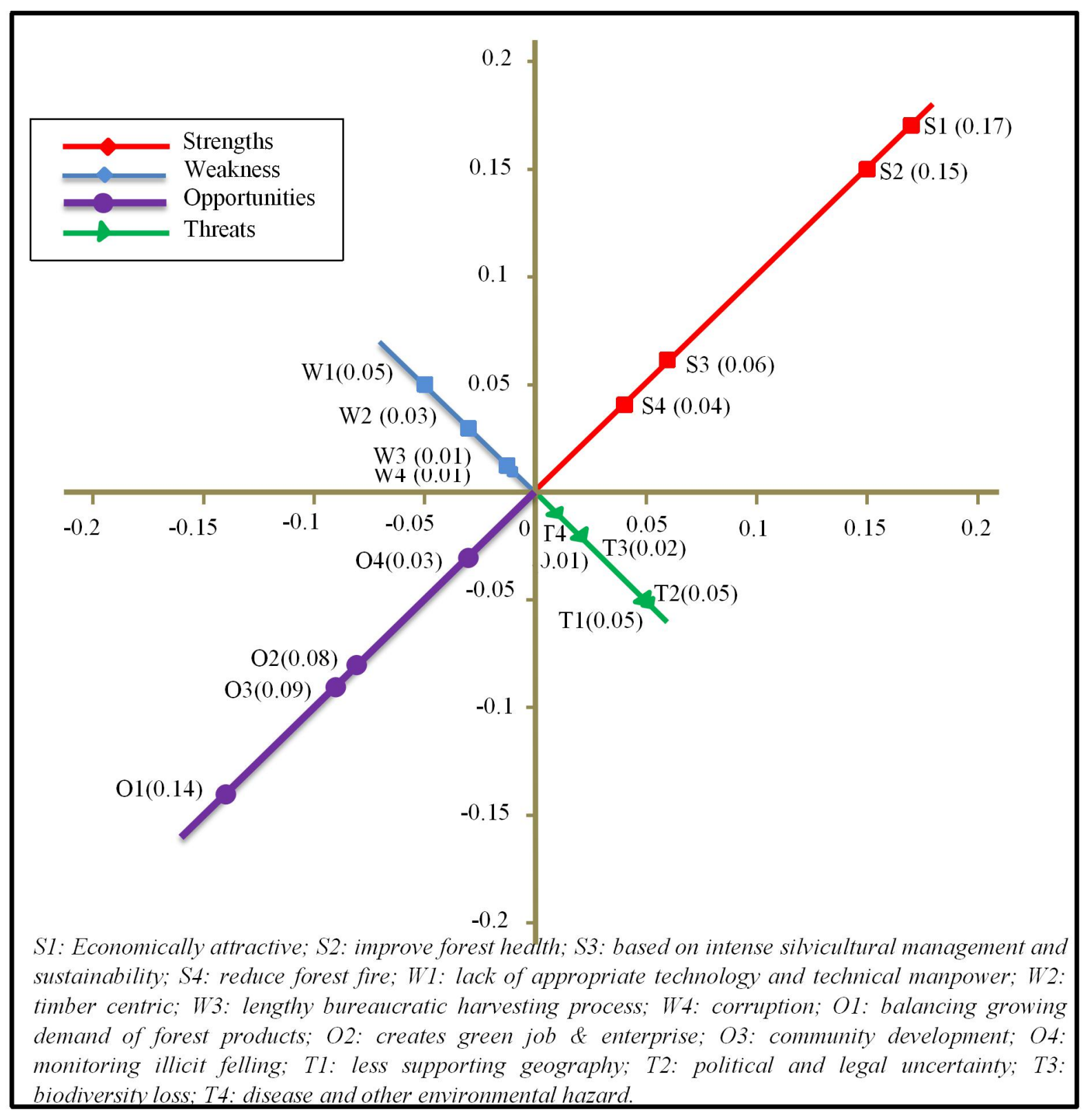

Figure. 3. Overall priority score of SWOT factors determined through AHP analysis with CF users 
In sum, CF users perceived that SciFM in CF of Nepal consequences positive vibes in spite of their inherent weakness. Increasing demand of forest products in one hand and presence of over matured quality trees in forest other hand demands the need of intensive silvicultural intervention in productive CF of Nepal (Jayasawal \& Bishokarma, 2016). Therefore, our study findings support the demands of active forest management in protection-oriented $\mathrm{CF}$ of Nepal in order to accomplish the goal of economic prosperity.

\section{Conclusions and Future Perspectives}

This study uses the SWOT-AHP method to provide important insights of CF users on SciFM in CF of Nepal. The result clearly indicated that CF users viewed SciFM as a step towards meeting the demand of timber within the country. As stated earlier, economically attractive was the strongest strength factor and balancing growing demand of forest products was viewed as most important opportunity, were also visible in our findings. Therefore, government of Nepal stressing expansion of active forest management in high value productive forest of Nepal (Jayasawal \& Bishokarma, 2016). If technical science with intense silvicultural operations are internalized through active forest management, the profitability of $\mathrm{CF}$ users in terms of economy and services would be more than the protection-oriented $\mathrm{CF}$ fallouts, CF users may adopt the active forest management more. Hence, profitability governs more in success and failure of SciFM in CF of Nepal.

Aside from the strengths, most important weakness viewed by CF users is lack of appropriate technology and technical manpower. Intensive silvicultural operation in this extent limited capable forestry technicians and efficient technologies (Joshi et al., 2018). Our study revealed that because of weak silvicultural knowledge and insufficient technological skills, CF users usually hire outsourced human resources, those resources mainly motive for their own benefits and always concentrated on completion of the work rather than facilitating and schooling CF users about science and silviculture of forest management. Limited capable technical human resources and weak technical and silvicultural knowledge of CF users, SciFM in CF of Nepal is not effective as it could be. Hence, greater complexities reduce the adaption rate of SciFM in Nepal. Furthermore, CF users deemed accepted needs of active forest management but their anxieties on long term implications of SciFM on biophysical, socio economic and environmental aspects of forest, which were rarely consulted with $\mathrm{CF}$ users before implementation. Hence, proper consultation and development of common 
understandings among the key stakeholders likely to improve the effectiveness of SciFM in Nepal. Additionally, lengthy government bureaucratic procedures and uncertain political situations of Nepal has created dilemmas in proper implementation of SciFM, as a result SciFM failed to gain proper participation, weak stakeholders support and lacks close government monitoring finally catalyzed institutional corruptions.

Finally, it should be noted that, positive aspects of the SciFM, viewed by CF users in our study revealed higher comparative advantages over negative aspects, indicating greater adaptation chances of CF users. Results derived in this study here indicate the views of CF users, who have knowledge and understandings of SciFM but do not include the perspective of other stakeholders; government officials, FECOFUN, researchers, I/NGO's, etc. A caution should be taken while using these findings in other stakeholders' perspectives.

\section{Acknowledgements}

I would like to acknowledge all the respondents for their kind co-operation and precious timing in spite of their busy schedule. My special thanks are also extended to Divisional Forest Office, Chitwan and Gorkha for their continuous support during field work.

\section{Appendix A}

\begin{tabular}{|c|c|c|}
\hline Importance & Level of importance & Explanation \\
\hline 1 & Equally importance & Two criterions equally contribute to the objective \\
\hline 3 & Moderate importance & Slightly favor one criterion over another \\
\hline 5 & Strong importance & Strongly favor one criterion over another \\
\hline 7 & Very strong importance & $\begin{array}{l}\text { Strongly over another criterion; demonstrated } \\
\text { importance }\end{array}$ \\
\hline 9 & Extreme importance & $\begin{array}{l}\text { Criterion over another affirmed higher probable } \\
\text { order }\end{array}$ \\
\hline $2,4,6 \& 8$ & \multicolumn{2}{|c|}{ Represent intermediate importance between the priorities listed above } \\
\hline
\end{tabular}

\section{Appendix B}

Result from the pair wise comparison are presented in reciprocal matrix where relative weight of the factor enters in the matrix as "aij" and it's reciprocal (1/aij) goes to opposite side of the main diagonal, 


$$
\mathrm{A}=(\text { aij })=\left(\begin{array}{cccc}
\mathrm{w} 1 / \mathrm{w} 1 & \mathrm{w} 1 / \mathrm{w} 2 & \ldots & \mathrm{w} 1 / \mathrm{wn} \\
\mathrm{w} 2 / \mathrm{w} 1 & \mathrm{w} 2 / \mathrm{w} 2 & \ldots & \mathrm{w} 2 / \mathrm{wn} \\
\vdots & \vdots & \ldots & \vdots \\
w n / w 1 & w n / w 2 & \ldots & \mathrm{wn} / \mathrm{wn}
\end{array}\right)
$$

Where, rows represent ratio of weight of each factor with respect to all others. In the matrix (eq 1 ) when $\mathrm{i}=\mathrm{j}$, then aij $=1$. Transpose of the vector weight $\mathrm{w}$, is multiplied with matrix A, we get subsequent vector aw (eq 2)

$$
A w=n w, \text { where } w=(w 1, w 2, \ldots \ldots w n)^{T}
$$

Eq 2 also can written as,

$$
(\mathrm{A}-\mathrm{nI}) \mathrm{w}=0
$$

Where, $\mathrm{n}$ also represent the largest eigenvalue, $\lambda_{\max }$, and $\mathrm{I}$ is the identity matrix of size $\mathrm{n}$. (Saaty, 1977) verified $\lambda_{\max }=\mathrm{n}$ is a required and satisfactory condition for the consistency. The matrix A must be tested in such a way that consistency should be within the excepted range. Following formula is use to test the consistency.

$$
\begin{aligned}
& \mathrm{CR}=\mathrm{CI} / \mathrm{RI} \\
& \mathrm{CI}=\frac{(\lambda \max -\mathrm{n})}{(\mathrm{n}-1)}
\end{aligned}
$$

Where, CI consistency index, RI is random index for random matrix of order $\mathrm{n}$ and $\mathrm{CR}$ is the consistency ratio (Saaty, 1977). In decision situation, some inconsistency can be encounter and therefore, consistency ratio below $10 \%$ is generally acceptable (Kurttila et al., 2000).

\section{References}

[1] Adhikari, B., Williams, F., \& Lovett, J. C. (2007). Local benefits from community forests in the middle hills of Nepal. Forest Policy and Economics, 9(5), 464-478. https://doi.org/10.1016/j.forpol.2005.11.002

[2] Awasthi, N., Aryal, K., Bahadur Khanal Chhetri, B., Bhandari, S. K., Khanal, Y., Gotame, P., \& Baral, K. (2020). Reflecting on species diversity and regeneration dynamics of scientific forest management practices in Nepal. Forest Ecology and Management, 474(June), 118378. https://doi.org/10.1016/j.foreco.2020.118378

[3] Bampton, J., \& Cammaert, B. (2007). How can timber rents better contribute to poverty reduction through community forestry in the Terai region of Nepal? Journal of Forest and 
Livelihood, 6(1), 28-47.

[4] Banjade, M. R. (2013). Discourse and Discursive Practices Over Timber in Nepal. Journal of Forest and Livelihood, 10(1), 58-73. https://doi.org/10.3126/jfl.v10i1.8601

[5] Baral, Sirjana, Meilby, H., Khanal Chettri, B. B., Basnyat, B., Rayamajhi, S., \& Awale, S. (2018). Politics of getting the numbers right: Community forest inventory of Nepal. Forest Policy and Economics, 91(October), 19-26. https://doi.org/10.1016/j.forpol.2017.10.007

[6] Baral, Sony, \& Vacik, H. (2018). What governs tree harvesting in community forestryregulatory instruments or forest bureaucrats' discretion? Forests, 9(10). https://doi.org/10.3390/f9100649

[7] Basnyat, B., Treue, T., \& Pokharel, R. K. (2018). Silvicultural madness: a case from the "Scientific Forestry" initiative in the community forests of Nepal. Banko Janakari, 54-64. https://doi.org/10.3126/banko.v27i3.20542

[8] Bhattrai, B., Mandal, R. A., \& Kurmi, R. R. prasad. (2017). First National Silviculture Workshop. In S. Adhikari, R. Karki, \& A. Gurung (Eds.), Policy Instruments and Practices of Collaborative Forest Management (p. 11). Department of Forests, Babarmahal, Kathmandu, Nepal.

[9] Bhusal, P., Awasthi, K. R., \& Kimengsi, J. N. (2020). User's opinion in scientific forest management implementation in Nepal-a case study from Nawalparasi district Public land Agro-forestry for Biodiversity Conservation, Livelihood Support and North-South Conflict Mitigation in Nepal Terai View project Commu. Cogent Environmental Science, 6(1). https://doi.org/10.1080/23311843.2020.1778987

[10] Boyce, J. . (1954). Forest plantation protection against diseases and pests. FAO.

[11] Demarais, S., Verschuyl, J. P., Roloff, G. J., Miller, D. A., \& Wigley, T. B. (2017). Tamm review: Terrestrial vertebrate biodiversity and intensive forest management in the U.S. Forest Ecology and Management, Vol. 385, pp. 308-330. https://doi.org/10.1016/j.foreco.2016.10.006

[12] Department of Forest. (2020). Community Forestry National Database: MIS Database. In Department of Forest (DoF). Kathmandu, Nepal.

[13] Department of Forest Research and Survey. (2015). STATE OF NEPAL' S FORESTS. In Forest Resource Assessment Nepal Project (FRA), Department of Forest Research and Survey (DFRS). Babarmahal, kathmandu, Nepal.

[14] Dhakal, M., \& Masuda, M. (2009). Local pricing system of forest products and its relations to equitable benefit sharing and livelihood improvement in the lowland 
community forestry program in Nepal. Forest Policy and Economics, 11(4), 221-229. https://doi.org/10.1016/j.forpol.2009.02.004

[15] Dwivedi, P., \& Alavalapati, J. R. R. (2009). Stakeholders' perceptions on forest biomassbased bioenergy development in the southern US. Energy Policy, 37(5), 1999-2007. https://doi.org/10.1016/j.enpol.2009.02.004

[16] Forest Action. (2014). Political Economy of Forestry Sector of Nepal Analysis of Actors Engagement and Policy Process. https://doi.org/10.13140/2.1.4310.5284

[17] Gilmour, D. (2016). Forty years of community-based forestry: A review of its extent and effectiveness. Rome: Food and Agriculture Organization of the United Nations.

[18] Government of Nepal. Community Forestry Program Development Guideline (Third Revision)., (2014).

[19] Government of Nepal. (2014b). Scientific Forest Management Guideline. Kathmanud, Nepal: Mnistry of Forests and Environment.

[20] Gurung, A., Bista, R., Karki, R., Shrestha, S., Uprety, D., \& Oh, S. E. (2013). Community-based forest management and its role in improving forest conditions in Nepal. Small-Scale Forestry, 12(3), 377-388. https://doi.org/10.1007/s11842-012-9217-z

[21] Hull, J., Ojha, H., \& Paudel, K. P. (2010). Forest inventory in Nepal - Technical power or social empowerment? In Taking Stock of Nature: Participatory Biodiversity Assessment for Policy, Planning and Practice (pp. 165-184). https://doi.org/10.1017/CBO9780511676482.008

[22] Jayasawal, D., \& Bishokarma, D. (2016). Scientific Forest Management Initiatives in Nepal: MSFP EXPERIENCES AND LESSONS LEARNT. In Multi Stakeholder Forestry Programme (MSFP). Kathmandu.

[23] Joshi, O., Parajuli, R., Kharel, G., Poudyal, N. C., \& Taylor, E. (2018). Stakeholder opinions on scientific forest management policy implementation in Nepal. PLoS ONE, 13(9), 1-15. https://doi.org/10.1371/journal.pone.0203106

[24] Khanal, Y., \& Adhikari, S. (2018). Regeneration promotion and income generation through scientific forest management in community forestry: a case study from Rupandehi district, Nepal. Banko Janakari, (4), 45-53. https://doi.org/10.3126/banko.v27i3.20541

[25] Kurttila, M., Pesonen, M., Kangas, J., \& Kajanus, M. (2000). Utilizing the analytic hierarchy process (AHP) in SWOT analysis - A hybrid method and its application to a forest-certification case. Forest Policy and Economics, 1(1), 41-52. https://doi.org/10.1016/s1389-9341(99)00004-0 
[26] Luintel, H., Bluffstone, R. A., \& Scheller, R. M. (2018). The effects of the Nepal community forestry program on biodiversity conservation and carbon storage. PLOS ONE, 13(6), 1-19. https://doi.org/10.1371/journal.pone.0199526

[27] Ojha, H. R. (2006). Techno-bureaucratic Doxa and Challenges for Deliberative Governance: The Case of Community Forestry Policy and Practice in Nepal. Policy and Society, 25(2), 131-175. https://doi.org/10.1016/s1449-4035(06)70077-7

[28] Pandit, R., \& Bevilacqua, E. (2011). Forest users and environmental impacts of community forestry in the hills of Nepal. Forest Policy and Economics, 13(5), 345-352. https://doi.org/10.1016/j.forpol.2011.03.009

[29] Poudyal, B. H., Maraseni, T., \& Cockfield, G. (2019). Impacts of forest management on tree species richness and composition: Assessment of forest management regimes in Tarai landscape Nepal. Applied Geography, 111,102078.

[30] Poudyal, B. H., Maraseni, T., \& Cockfield, G. (2020). Scientific forest management practice in Nepal: Critical reflections from stakeholders' perspectives. Forests, 11(1). https://doi.org/10.3390/f11010027

[31] Rights and Resources Initiative. (2014). What Future For Reform? Progress and slowdown in forest tenure reform since 2002. Washington DC: Rights and Resources Initiative (RRI).

[32] Rutt, R. L., Chhetri, B. B. K., Pokharel, R., Rayamajhi, S., Tiwari, K., \& Treue, T. (2015). The scientific framing of forestry decentralization in Nepal. Forest Policy and Economics, 60, 50-61. https://doi.org/10.1016/j.forpol.2014.06.005

[33] Saaty, T. L. (1977). A scaling method for priorities in hierarchical structures. Journal of Mathematical Psychology, 15(3), 234-281. https://doi.org/10.1016/0022-2496(77)900335

[34] Saaty, T. L., \& Vargas, L. G. (2012). Models, Methods, Concepts \& Applications of Analytic Hierarchy Process (Second Edi). New York: Springer Science + Business Media New York.

[35] Sapkota, L. M., Dhungana, H., Poudyal, B. H., Chapagain, B., \& Gritten, D. (2020). Understanding the Barriers to Community Forestry Delivering on its Potential: An Illustration From Two Heterogeneous Districts in Nepal. Environmental Management, 65(4), 463-477. https://doi.org/10.1007/s00267-019-01224-0

[36] Shrestha, R. K., Alavalapati, J. R. R., \& Kalmbacher, R. S. (2004). Exploring the potential for silvopasture adoption in south-central Florida: An application of SWOTAHP method. Agricultural Systems, 81(3), 185-199. 
https://doi.org/10.1016/j.agsy.2003.09.004

[37] Stainback, G. A., Masozera, M., Mukuralinda, A., \& Dwivedi, P. (2012). Smallholder Agroforestry in Rwanda: A SWOT-AHP Analysis. Small-Scale Forestry, 11(3), 285-300. https://doi.org/10.1007/s11842-011-9184-9

[38] Subedi, B. P., Ghimire, P. L., Koontz, A., Khanal, S. C., Katwal, P., Sthapit, K. R., \& Mishra, S. K. (2014). Private Sector Involvement and Investment in Nepal's Forestry: Status, Propects and Ways Forward. Babarmahal, kathmandu, Nepal: Multi Stakeholder Forestry Programme (MSFP).

[39] Subedi, V. R., Bhatta, K. D., Poudel, I. P., \& Bhattarai, P. (2018). Application of silvicultural system, yield regulation and thinning practices in natural forests: case study from western Terai. Banko Janakari, (4), 92-97. https://doi.org/10.3126/banko.v27i3.20553

[40] Wheelen, T. L., \& Hunger, J. D. (2010). Concepts in Strategic Management and Business Policy (12th ed.). Noida, India: Dorling Kindersley (india) Pvt. Ltd.

[41] Yadav, N., Yadav, K., Yadav, K. K., \& Thapa, N. (2009). Facilitating the Transition from Passive to Active Community Forest Management: Lessons from Rapti Zone, Nepal. Journal of Forest and Livelihood, 8(2), 51-66. https://doi.org/10.3126/jfl.v8i2.2308 